\title{
A soluble guanylate cyclase activator protects from diabetic nephropathy beyond standard of care in the ZSF1 rat
}

\author{
Steven S Pullen*, Kathleen A Lincoln, Paul C Harrison, Hongxing Chen, Hong Wang, Holly Clifford, HuSheng Qian, \\ Diane Wong, Chris Sarko, Jehrod Brenneman, Ryan Fryer, Jeremy Richman, Glenn A Reinhart, Carine Boustany \\ From 7th International Conference on cGMP Generators, Effectors and Therapeutic Implications \\ Trier, Germany. 19-21 June 2015
}

The pathogenesis of diabetic nephropathy is associated with abnormalities of renal nitric oxide generation and signaling. We evaluated the effect of BI 684067, a soluble guanylate cyclase (sGC) activator, in combination with the current standard of care (SoC), on the progression of diabetic nephropathy. Male ZSF1 rats were administered enalapril ( $3 \mathrm{mg} / \mathrm{kg}$ in drinking water) for 10 days, after which they were randomized to either continue to receive enalapril alone or the combination of enalapril and one of three doses of BI 684067 (20, 40 and $80 \mathrm{mg} / \mathrm{kg}$ ) in chow for 10 weeks. Weekly urinary protein to creatinine ratio (UPCR) as well as daily mean arterial pressure (MAP) and heart rate (HR) were measured. At study end, kidneys were assessed for glomerular lesions and $\alpha$-SMA expression, a marker of myofibroblast activation. The combination of BI 684067 and enalapril resulted in significant dose-dependent decreases of the following when compared to enalapril alone: UPCR (BI 684067 at 20,40 , and $80 \mathrm{mg} / \mathrm{kg}: 27,39,48 \%$ reductions respectively), incidence of glomerulosclerosis (BI 684067 at 20,40 , and $80 \mathrm{mg} / \mathrm{kg}: 29,32,44 \%$ reductions, respectively) and $\alpha$-SMA expression (BI 684067at 20, 40, and $80 \mathrm{mg} / \mathrm{kg}: 26,40,42 \%$ reductions, respectively). The MAP was significantly reduced by BI 684067 in combination with enalapril $(-3 \mathrm{~mm} \mathrm{Hg}$ vs enalapril alone at the doses of 40 and $80 \mathrm{mg} / \mathrm{kg}$ ), however there was no significant effect on HR. These results support the efficacy of an sGC activator in preventing the progression of diabetic nephropathy when combined with the SoC.

\footnotetext{
* Correspondence: steven.pullen@boehringer-ingelheim.com CardioMetabolic Disease Research and Medicinal Chemistry, Boehringer Ingelheim Pharmaceuticals Ridgefield, CT, USA
}

Published: 2 September 2015

\section{doi:10.1186/2050-6511-16-S1-A4 \\ Cite this article as: Pullen et al:: A soluble guanylate cyclase activator protects from diabetic nephropathy beyond standard of care in the ZSF1 rat. BMC Pharmacology and Toxicology 2015 16(Suppl 1):A4.}

Submit your next manuscript to BioMed Central and take full advantage of:

- Convenient online submission

- Thorough peer review

- No space constraints or color figure charges

- Immediate publication on acceptance

- Inclusion in PubMed, CAS, Scopus and Google Scholar

- Research which is freely available for redistribution

Submit your manuscript at www.biomedcentral.com/submit
() Biomed Central 